\title{
FEATURE Agricultural sustainability: Five midwestern row crop farmers share their views
}

\author{
Lynn Laws
}

n mid-July of 2016, I visited and interviewed five corn (Zea mays L.) farmers in central Michigan and southwestern Indiana, United States, to hear their thoughts about the sustainability of farming, through the lenses of their careers and operations. I was introduced to the farmers through their area Extension specialists. Each farmer had a history of conservation and had in some way cooperated with studies being conducted by USDANational Institute of Food and Agriculture (NIFA) funded Climate and Corn-based Cropping Systems Coordinated Agricultural Project. Their comments provide insight into the opportunities identified, questions asked, and challenges faced by farmers as they balance economic, environmental, and social concerns while running their farms.

\section{BRIAN BOGE}

"Meeting the economic needs of my family through my farm operation and being accountable to our environment, the world around us-sometimes those two things don't mesh," said Brian Boge. "I do the best I can, and I think about sustainability and this balancing act all the time."

Boge, age 43, raises corn, soybeans (Glycine max [L.] Merr.), and wheat (Triticum aestivum L.) on 374 ha $(925 \mathrm{ac}$ ) in Isabella County, in central Michigan (figure 1). He and his wife have been farming for 22 years. He grew up in Waterford, a small suburb of Detroit. On weekends and during the summers, he visited family members who farmed in central Michigan. He wanted to be a farmer since the fourth grade, but for a long time could not find a way to get started. He had no money to buy land or equipment. So instead, he went to Central Michigan University to earn a teaching degree and worked on farms on weekends and during the summer.

Lynn Laws is a communications specialist for lowa State University College of Agriculture and Life Sciences, Ames, lowa.

\section{Figure 1}

Brian Boge with his son Jason, age 9, and daughter Allison, age 6.

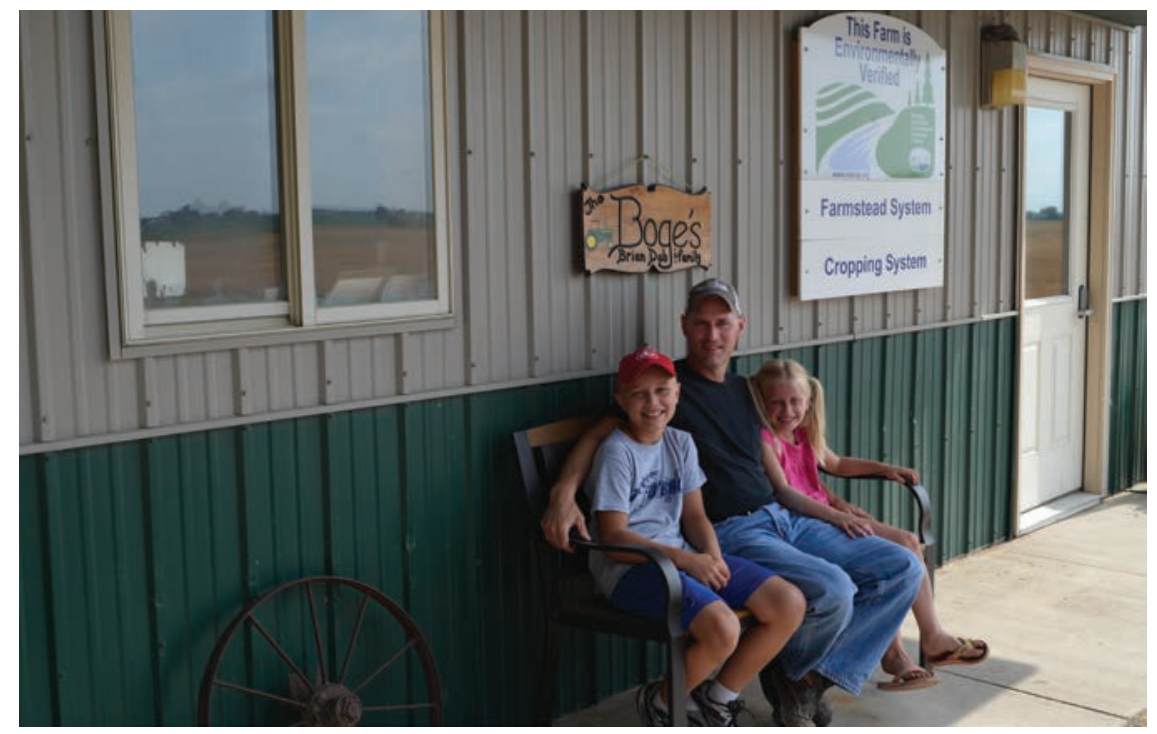

"That was my way in," said Boge. "I was milking cows here, and one of the neighbors was retiring. That was in ' 94 and, of course, times have changed dramatically. In '94 land values were way lower; cash rents were way lower. Not to say it was easy to get started because it wasn't, but it would be impossible today to do what I did then."

Boge's neighbor agreed to rent him the land. He borrowed money from his dad to buy his first 4020 John Deere tractor. He and his wife, Deb, were married a year later.

"I was farming and student teaching. We were both working two jobs. And I was renting land and renting buildings for a long time because I had no capital and no equity to buy anything other than some small equipment," said Boge.

In 2002, he made his first land purchase. He now owns 192 ha (475 ac) and rents 182 ha $(450 \mathrm{ac})$. His farmland is in the Chippewa River watershed, which drains into Saginaw Bay. His farmstead and cropping systems are "environmentally verified" by the Michigan Agricultural Environmental Assurance Program, a voluntary program that helps farms of all sizes and all commodities prevent or minimize immediate risks of groundwater and surface water contamination and implement cost effective best management practices for water management, soil conservation, and nutrient and pest management.

"Water management and getting rid of excess water has been a huge goal," said Boge. For eight years he's been using cover crops that overwinter-vetch [Vicia hirsuta L.], clover, and peas-to build the health, organic matter, and water holding capacity of the soil. He's using gypsum to help with soil structure. He's traded straw for manure or paid to have manure hauled in. The cover crops have helped keep the manure from leaving the growing profile but create a challenge in the spring.

"Our biggest issues with the cover crops is our springs go from winter to planting season-there's no in-between. This year we had the ground covered with snow in May before we planted. All these cover crops that overwintered leave me no options in the spring as far as time to terminate them. And what happens on a year when we have a wet spring is they just get out of control. They grow so fast you can't get in there and spray them, and the next thing you know, you have vetch that's this 
tall, and then it dries off and it has sucked all the moisture out, and you can't get it killed and worked down. In my opinion, I've lost a lot of money using cover crops, yet I'm still doing it because it's a sustainable thing. It's done wonderful things for the soil-the manure and the tons of organic matter that I grew and then put back into the soil. But it's probably going to cost me money again this year because I planted corn later.

"I was talking to Paul [his Extension agent] the other night. He said, 'You're doing great things for the soil for the years to come.' I said, 'Well, what if I'm not in business next year?'That's the balancing act with this whole sustainable thing, that I'm always twisting in my head-I know what I need to do, I know how to be sustainable, I know how to do these things and what needs to be done. But I have to balance it somehow. I can't take a 20 bushel [544 kg] hit on my wheat every year. I can't take a 50 bushel [1,270 kg] hit on my corn.

"My long-term goals are to build the soils, raise cover crops, and do all these things that I would like to do and get the drainage figured out [he's been installing subsurface drainage tiles and has planted a grass waterway] — and in 20 years look back and say it was a struggle, but look what we have got now. It's just a matter of making sure I can get there. And it wasn't as hard five years ago as it is now. The economics have changed on these things in the last couple years because of crop prices. It's not as easy to go out there and spend US $\$ 25$ on a cover crop per acre [US\$62 ha ${ }^{-1}$ ] and maybe take a 20 bushel [508 kg] hit on your corn the next year. Those numbers are your profits. So if that's actually the case, is it worth doing? Can you afford to do that? And that's the balancing act.

"The small family-run ones - those are the ones that are hurting the worst. Not to say the big ones aren't hurting. Not to say that the corporate ones aren't hurting. They all are. But the ones that are probably going to go out of business or be hurt so bad in the sustainable thing we talked about, like me being able to be here next year, are the small ones," said Boge.

Nonetheless, he believes small, environmentally friendly farming is sustainable.

\section{DAVE AND NATHAN CLARKE}

Like Brian Boge, Nathan Clarke worries about the economic sustainability of his family's farming operation (figure 2). He feels the pressure of the generations. It keeps him up at nights. farmer. $\mathrm{He}$ and his father, Dave Clarke, 63, have a large family farm-728 ha $(1,800 \mathrm{ac})$, in Midland County, in central Michigan. They have rotations of corn, soybeans, dry edible beans, and cucumbers (Cucumis sativus L.) for pickling, a common niche crop in Michigan. Dave has another son, Aric, who farms too, and a daughter, Abby, who is a team leader at Dow Chemical.

"This is the home farm here, and this is one of our sandiest pieces. It blows the worst of any. As I grew up I saw my grandpa, Arthur, plant cover crops. I don't ever remember there not being a cover crop on this farm," said Dave.

Winter rye (Secale cereale L.) was a typical cover crop in his grandfather's time to be grown in rotation with seed potatoes (Solanum tuberosum L.). As Dave and Nathan expanded the family operation, they always added cover crops to their rotations on sandy soils, to slow wind erosion. They are now adding cover crops to
Nathan, age 32 , is a fifth generation fields with heavier clay soils to increase soil health. Over 405 ha $(1,000 \mathrm{ac})$ are now cover-cropped.

"We're always measuring soil fertility and keeping track of that. We want to go to less tillage and more cover crops. I think the more we can keep green roots in the ground, the better off we're going to be. We're just going to keep working towards that," said Dave.

They've tried different types of cover crops-oilseed radish (Raphanus sativus L.), hairy vetch - but rye has had the least amount of challenges. He and Nathan agree that as equipment has evolved and if people make an effort, it is possible to "keep our topsoil and improve soil fertility."

Dave says farmers can move toward more conservation practices by "just being conscious of it and trying, to use less tillage and more cover crops. The old farms, they'd bale the straw and make manure out of it and put it back on. Well, that was great. But in today's world, not everybody has cattle, so don't sell your straw-put it back on the field and leave it in the field when you thrash your grain."

"And if we can't get manure, we try to grow it-green manure," added Nathan.

Last year Dave and Nathan added a second cover crop: oats (Avena sativa L.),

\section{Figure 2}

From left: Adam Clarke, age 9; Nathan Clarke; Marilyn Thelen, Michigan State University Extension; and Dave Clarke.

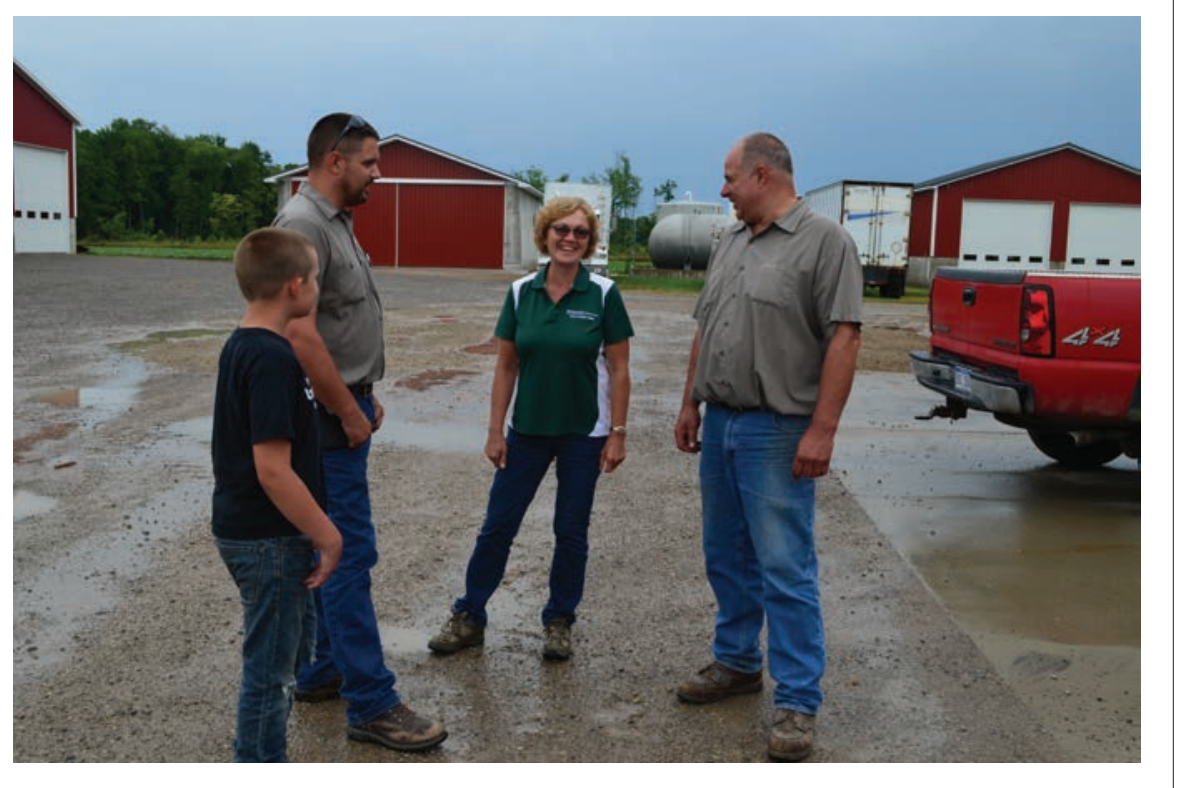


which are less expensive than rye and can be used as fall grazing or cutting for hay, for beef production.

Nutrient Application. The public often hears about the issues of phosphorus (P) loading in Michigan lakes. Significant P loading of lakes and streams has been documented since the mid-1980s. Less has been published about nitrate $\left(\mathrm{NO}_{3}\right)$ contamination in Michigan waters. However, nitrogen (N) contamination of groundwater in areas of Michigan has been documented (Michigan Department of Agriculture and Rural Development 2016). The Clarkes have been aware of the issues and have sent soil sample tests through Michigan State University for years.

"We're trying to be conscious that way, but we always have to be conscious of our bottom line also. I mean part of sustainability is you make a profit at the end. We do monitor our soil really close for what nutrients we need, and we only put on what we need because of economics,' said Dave.

Nathan said he doesn't know why farmers would not use the knowledge and tools available to them today to apply only the fertilizer needed. They do soil sampling by grids and then apply fertilizer based on what each grid needs. Before they worked on averages. Now they're putting nutrients only when and where needed.

"It's so easy and the economics of ityou don't really have to be that big of a farm to make it pay, to buy the hardware that it takes to be able to variable rate apply fertilizer. That's been the best thing we've done in quite a few years, economically," said Nathan.

$\mathrm{He}$ said $\mathrm{N}$ is "the one area where we're behind on technology a little bit."

"We sidedress our corn; I'm still a firm believer in not putting it all up there ahead of time. But I know some people pull tissue samples in season before they sidedress, and we don't do that. I don't know if we should. We did it one year and had kind of mixed results with it."

Dave and Nathan say the effects of climate change have not been a big issue for them. However, for Indiana farmer Tim Hoenert, climate change is a current and future threat to his operation.

\section{TIM AND KYLE HOENERT}

"I think one of the biggest things right now is climate change. Weather seems more erratic than it used to be. It seems the window to put the crop in the ground... it seems like if you miss one day, you've missed an opportunity for maybe two or three weeks. Our opportunities to plant are shorter and our rain events are more harsh. When it comes to rain, it's either feast or famine. We're trying to install more tile to help drain the fields to allow us to plant in that short window,' said Hoenert.

Tim Hoenert (figure 3), 52, graduated from Purdue University in 1986, with a degree in engineering. After graduation he rented a small piece of land, bought some gilts, and raised hogs with his father. His father retired five years ago, and Tim got out of the hog business and into row cropping. Now he farms with his son, Kyle, in Posey County, Indiana, on 546 ha $(1,350$ ac), 81 ha $(200 \mathrm{ac})$ of it owned. Kyle, now 26 , joined his father in the family business when he graduated with a two-year degree in agribusiness in 2012. They raise corn, soybeans, wheat, and, when flooding from the Wabash River is not an issue in their bottomland, some grain sorghum (Sorghum bicolor L.).

\section{Figure 3}

From left: Kyle Hoenert; Tim Hoenert; and Hans Schmitz, Purdue University Extension.

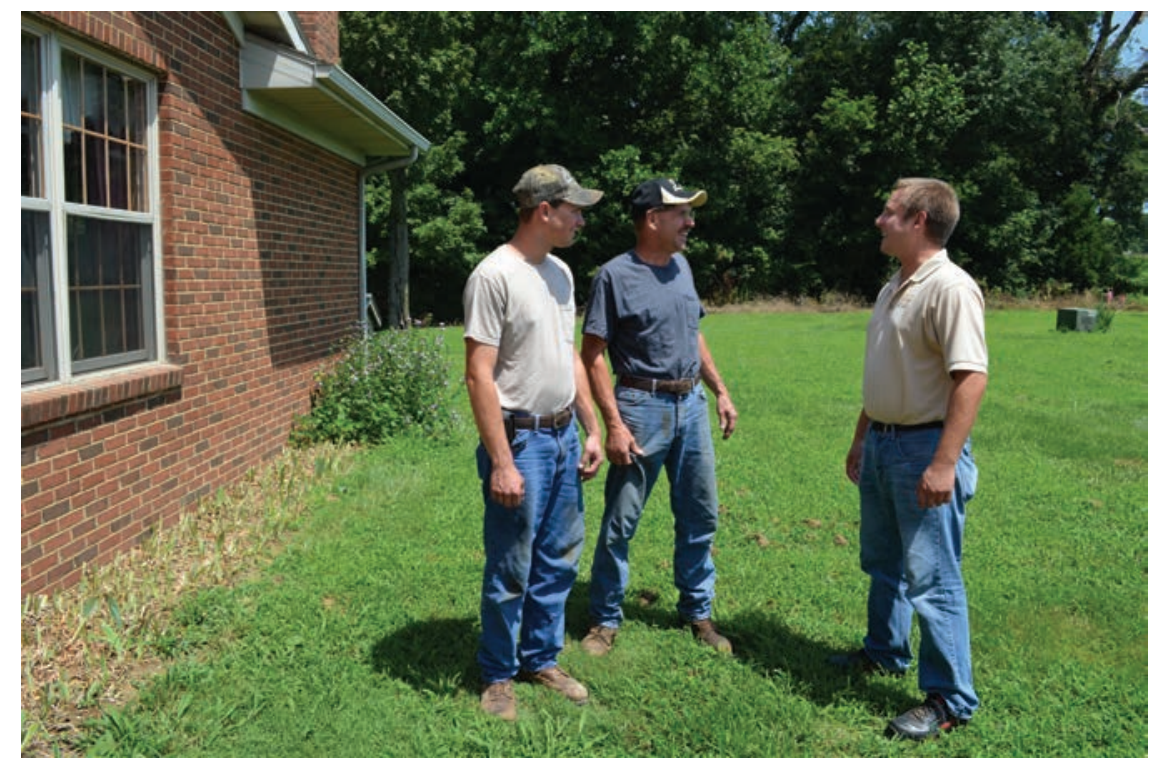

As a row cropper, Tim views soil as his major asset and works to conserve it. $\mathrm{He}$ does some conservation tillage and has some waterways and a lot of sediment control basins. He began experimenting with a cereal rye cover crop in 2015. He's hoping the rooting characteristics of a winter cover crop will eventually help him eliminate the deep tillage pass they have historically done every other year and improve or at least sustain soil health.

"All of our highly erodible ground gets wheat every other year, so at least $50 \%$ of the winters, it's got a cover on it. And if we could put a cover on it behind doublecrop soybeans, then it'd have a cover every winter. Our window to get a cover crop established is pretty short. Most of our ground that does not get wheat has flooding potential. So I'm not sure about cover crops in that scenario," said Tim.

Sustainability. Tim describes sustainable farming as "a loop that keeps working, that doesn't in the process eliminate something that's vital in that loop, whether that be soil, or some way to control weeds, or fertility. And the financial part has to work, too. Our goal is to take care of Mother Nature and try to make an income while doing that."

"But if you're looking at the big picture - sustainability of a society - then it's 
bigger than that. It includes the farmer as part of the community. He's not only a food source, he's also a consumer of machinery, fuel, oats, hardware, and so forth," said Tim.

Famers, like Tim and the others I interviewed, also provide leadership services for their community. Tim served on the Posey County Soil and Water Board and is now actively participating on the county drainage board. He has also agreed to serve on the steering committee of a watershed project that's just getting underway.

"If you're not involved in the community, whenever it comes time to plant and put you it in the ground, who cares if you were the biggest operator, the biggest farmer - that's never mentioned. It's who helped the community move on. I mean, money's not everything. And no farm or farmer is an island. If you're not involved with community, trying to better the life of everybody around you, why do it? So, I just try to help to a certain extent," said Tim.

\section{JAMES DROEGE}

Farmer James Droege, age 66, is a leader in his community (figure 4). He has been involved with the local Soil and Water District for "umpteen years," served on the state board, and was the state president of the district for two years. He has also served on the County Farm Bureau Board. Currently, he helps operate a program through his church that supports the Posey County food pantry.

He started farming as a freshman in high school through the National Future Farmers of America Organization (FFA). From 1969 to 1971 he was in the armed forces. During that time, his father, Edmund, and his brother, Paul, ran the operation. He began farming again when he returned home in 1971.

"After I got out of the service, I took advantage of the GI Bill and went to the University of Southern Indiana. I left that institution with a bachelor of accounting degree. That's been helpful to me in the business here from a variety of standpoints."

He and his brother, farm 567 ha $(1,400$ ac) in Posey County, in the southwestern corner of Indiana. In 2016 they planted 405 ha $(1,000 \mathrm{ac})$ of corn and $162 \mathrm{ha}(400$ ac) of beans. But most years their beans are

\section{Figure 4}

From left: Paul and James Droege.

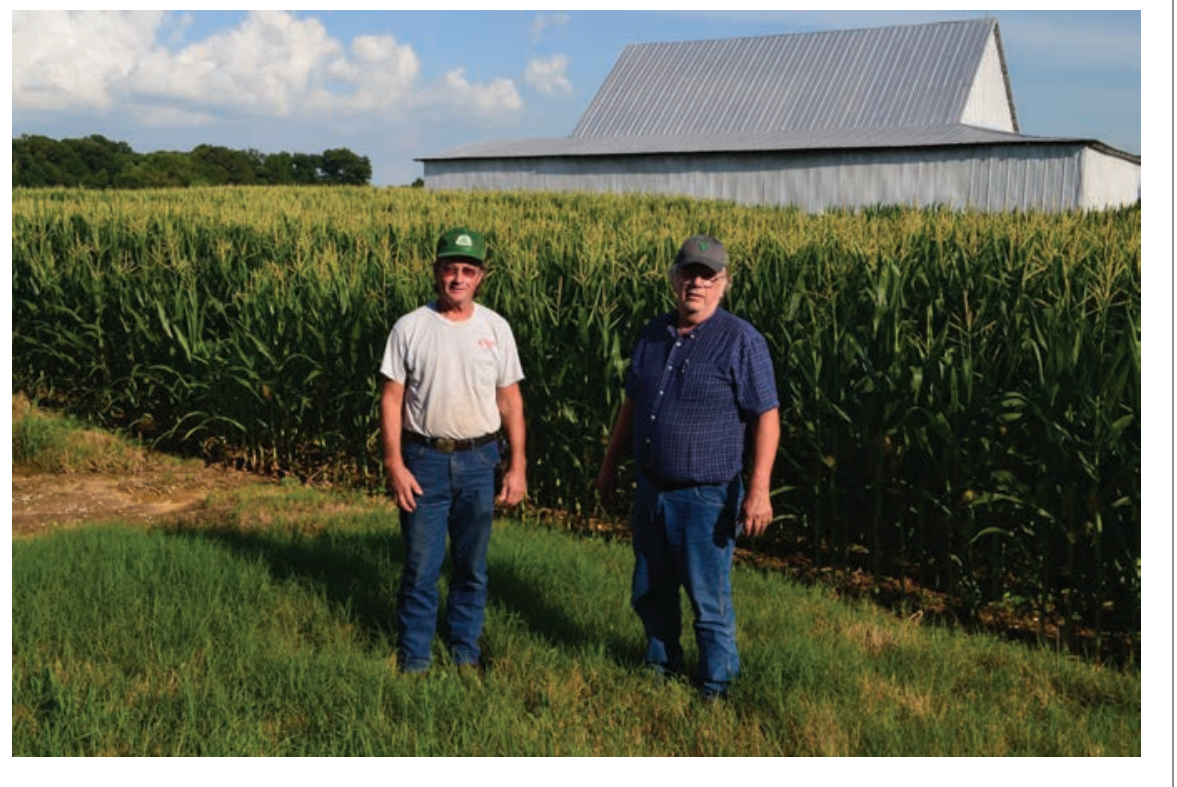

a double crop behind wheat, with only a small area of full-season spring beans. All their soybeans are non-genetically modified (non-GMO) for a specialty market. Some of the corn is continuous corn, and some is rotated with wheat and beans.

Droege said, "Over the years we have become increasingly concerned about the amount of tillage we do, trying to lessen it, while managing the amount of residue, which can be a problem for planting in the spring."

His conservation efforts progressed as he learned from university Extension and watched what others were doing and then experimented on his own land. In the past he's tried cover crops-hairy vetch and wheat as a cover crop. But he doesn't use cover crops now.

"Cover crops, I think, have tremendous benefit from a biological standpoint, from a carbon capture standpoint, and maybe even to strategic planning for altering soil structure in a positive way. The challenge is a timing issue here. In this two-man operation, it is really difficult to add substantially more demands on yourself in the fall of the year," said Droege.

He defined the challenges of farming as "enormous" and remarked on how fast new technology is emerging. "For somebody who is currently 66, it feels like it's exponential."

The technology, he says, is heralding in a new challenge. "We can collect mountains of data now, mountains of it. Now how do we put it all together to make some intelligent management decisions?"

Droege said many aging farmers he knows cannot invest in new technology. "It doesn't make economic sense for some. Ag is increasingly becoming a capital-intensive business. It's nothing to have a million dollars' worth of equipment. It somewhat depends on size, but it can come to the point where you've got a quarter of a million dollars in a corn planter, you've got US\$300,000-plus in a combine, and you can just keep going down the list. It has historically, and I suspect may always have a relatively low return on investment," said Droege, who quickly added, "Although, the GPS [global positioning system]-controlled row units on a planter - that had a two-year payback on it, just in seed savings alone."

"I think we have this tendency to live in the world that we know. It's rather limited, and if we can kind of back away and perhaps get a little bit of a historical perspective on things it helps. And that has led me to this: this soil is an incredible, diversified, magnificent living organism and the viability of a civilization depends on how 
we treat the soil over the long term. But I have a brief snippet of time to contribute. The application of technology, the application of the best of the knowledge that we have at this point in time is what we try to apply to what we do," Droege said.

\section{FRANK BENDER}

Frank Bender, 58, is an advocate for no-till and cover crops and raises corn and soybeans on 809 ha $(2,000 \mathrm{ac}), 162$ ha (400 ac) of it owned, with one full-time farm assistant (figure 5). He was raised on a farm in Posey County in southwest Indiana, where the Wabash and the Ohio rivers meet. His grandfather, father, aunt, and uncle all farmed. When he graduated from Purdue in 1980 in agricultural economics, he and his wife entered the John Deere implement business with his brother. But as the 1980s farm crisis wore on, Bender left the implement business and began farming with his uncle, Benjamin Bender.

The Culture of Tillage. "Benny was a very conventional farmer," said Bender. "What I mean by that is, the tillage practices that he maintained were very intense-very little residue left on top of the soil. He had developed a farming practice from the days of horses up to these days. There wasn't always the fertilizer as we know it today and the herbicides. So a big part of farming was tillage to help get the ground in shape for planting. As an example, our planters today can no-till into very rough terrain and the old planters could not. In that situation, they wouldn't even put seed in the ground; they would just drag along and bunch up. So residue was not an option back in those days. To my uncle's credit, he was a very good farmer. He grew up farming and had perfected what worked for him over a 65-year period."

As the farm crisis eased, income went up, and debts went down, Bender was able to buy out his uncle. He could not afford to purchase all of the tillage equipment his uncle had amassed over the years and, anyway, he was hoping to make fewer trips across the field to plant. While those decisions were based on economics, they also fit with his desire to reduce soil erosion.

"I've always been concerned with just how much mud was sliding off the fields and the gullies that were created," said
Bender, whose first soil conservation practice was no-till, much to his uncle's dismay.

"Benny was probably one of the proudest men I knew, and to see someone come in and not do tillage was really an insult to him, because it wasn't socially acceptable to leave the tillage equipment in the barn, you know. All of his peers and the next generation were still doing heavy tillage - and it worked for them. Success is measured in a lot of ways. When you talk about the economics of it and you see one who has established a nice farm base and they have land ownership and security and the extension of this into other family members, this is success. And that's what he and others measured," said Bender.

Bender recalled one day when some friends of his uncle came by to sell him Pioneer corn.

"My uncle was renting me land at this time, and he was out of the business. It was my baby. These guys were heavy tillage guys - great farmers, great guys in the community, but they had a very strong mindset on what needed to be done as far as cultural practices."

Bender continued, "So it's wintertime. We're in the shop talking and outside it's all standing cornstalks. I'm working in the shop cleaning up something, because Benny liked everything really clean, and one of the guys looks out the window a

\section{Figure 5}

Frank and his son, Dale, Bender.

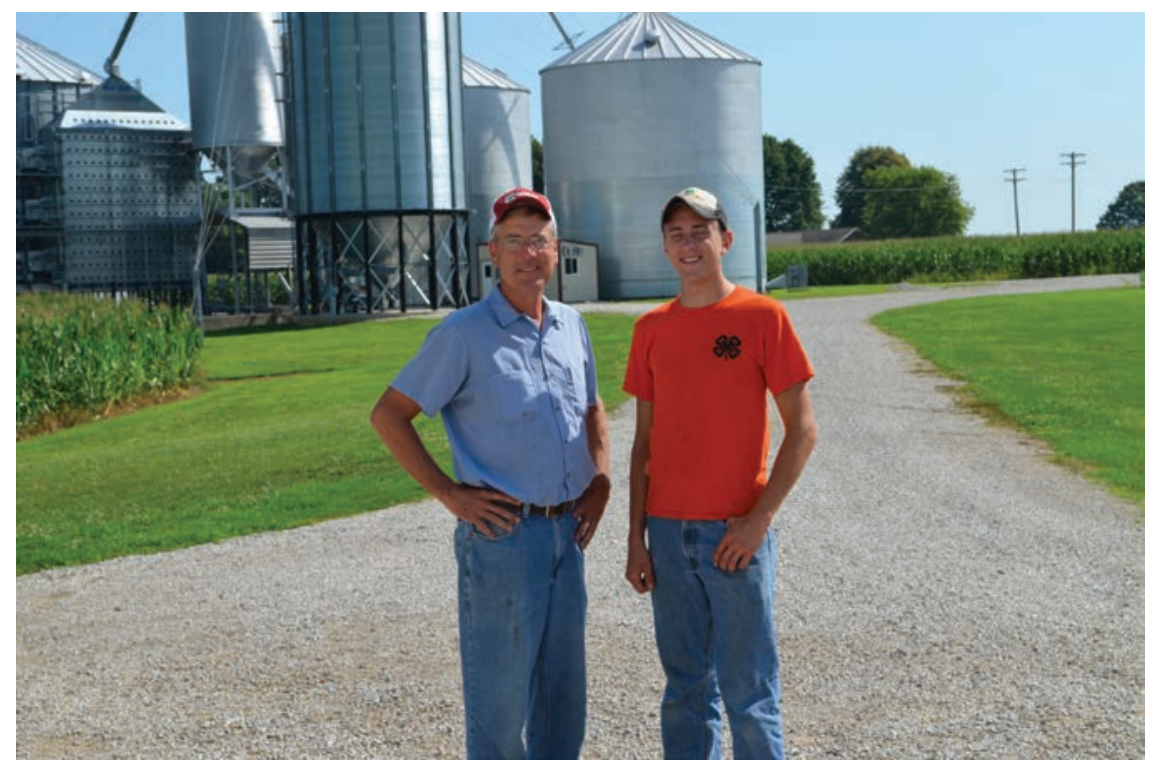

couple times and then he said to Benny, 'So are you not going to farm that next year?'

"It started at about Benny's collar: the blood pressure just rose, and the veins came out and all the way up, and he started sweating. It absolutely hit a nerve with him because not tilling just wasn't acceptable. But things were working and he could see the change."

Changing Times. Today, at the local coffee shop and at other times, landlords and neighbors tease Frank Bender about no-till, which he says he can easily laugh

"Now I'm finding, especially with the advent of cover crops, people are interested in these things and they're seeing some of the benefits," said Bender."Some of my landlords are actually very passionate about it and very appreciative of seeing improvements in their farms. By making these improvements and swallowing a lot of the cost of those things on my own in order to improve that farm, I get a confidence built between the landlord and me. I feel like that's a good way to drive relationships and I'm hoping to prove to them that this asset, which they've invested a lot of hard-earned money into, this farm ground, is appreciating if I'm the farmer on it, regardless of what the market is doing."

Other farmers now come to him with questions. He attributes that to the fact that he's an extrovert and attends a lot of field days. off. Moreover, he's seeing the tide turn. 
Two years ago, Bender and his cover crop seed salesman hosted a forum for farmers interested in learning about cover crops. Ten farmers attended. They held the forum again last year and 43 farmers attended. Not all have planted cover crops as a result, but most have begun experimenting on 20 ha $(50 \mathrm{ac}$ ) or so.

Bender tells them, "Try it somewhere where you won't see it. Don't put it out your living room window. Put it somewhere where you don't have to dwell on it, success or failure, because there's going to be both. And don't put it on a common road. Put it where nobody knows you even did it, unless they have a drone," said Bender.

Reaping the Benefits. I asked Bender what he would say to farmers who may be concerned about not seeing an immediate financial return for their investment in cover crops.

"We don't go to the mailbox in the spring and get a check based on our performance on planting a cover crop in the fall. But if we plant wheat in the fall, come summertime, we get a check for it. We see a direct correlation between what we put into it and what we get out. On cover crops, I can't actually say exactly when I'm getting the investment back. But what I have seen is that it greatly increases soil water infiltration and it reduces erosion," said Bender.

He began experimenting with cover crops on his field when the local Soil and Water Conservation District was offering US $\$ 50 \mathrm{ha}^{-1}$ (US $\$ 20 \mathrm{ac}^{-1}$ ) to farmers to plant cover crops.

"Even that first year, where I had tried it on 50 acres [20 ha], there was a noticeable difference on that particular field. I immediately saw the difference in erosion control. And this was on very highly erodible ground and on a farm that had been a no-till corn-soybean rotation for at least 12 years. Even though it was no-till, I was still seeing erosion down between the corn rows. We have a lot of ditches that are headed to the river. We have a lot of tree lines...that are just susceptible to a lot more gully erosion. So when I saw that immediate reduction on the cover-cropped land, then a light kind of went off. I knew this is what I needed to be doing."

Bender's next concern was selecting cover crops that were manageable in the spring. "I didn't want to make any more headaches for myself in the spring. Because it's no doubt easier, first of all, to conventionally farmtake a field cultivator out, crack the ground open, and let it dry. But when you start to put a cover crop in there, now it's a matter of timing. When do you kill it? You try not to create a mat on the ground so that it holds moisture.You can't plant into mud."

Bender was also worried about slugs, boles, and other crop pests that cover crops might attract.

"But we're learning in the process. There are complications with conventional tillage, too. Anyway, what I saw was the erosion control. And then, on my own, I started a little bit more and a little bit more, and then finally there was some EQIP [Environmental Quality Incentives Program] money available."

He was already participating in EQIP. He was doing nutrient and pest management; variable rate technology with lime, fertilizer, herbicides, and insecticides; and no-till. With the addition of cover cropping, he received US $\$ 197$ to US $\$ 222 \mathrm{ha}^{-1}$ (US $\$ 80$ to US $\$ 90$ $\mathrm{ac}^{-1}$ ) for his conservation practices.

"That's been an awesome program. Last year I had about 300 acres [121 ha] that were involved in that. I had about 1,900 acres [769 ha] of cover crop last year. So obviously 1,600 [647 ha] of the cost was out of my own pocket. I think it's always a battle when you look at agronomics versus economics on a farm. I really don't understand all the agronomics, but I like the things that I'm changing."

Bender continued, "The bottom line on this business that I'm running here is: I'm trying to make it leaner and more efficient and more profitable. And going this avenue of the cover crops and the no-till is a route that I've chosen because I truly believe that this has a long-term benefit to this soil."

Growing Interests. Slowing erosion used to be the number one environmental benefit Bender saw from no-till and cover crops. But that's changing.

"Now I've kind of evolved. The erosion part of it is probably $25 \%$ of the total picture; $75 \%$ is the benefit of the biological things that are happening in the soil and the aggregation and the structure of that soil and the water infiltration capacity - all these things that I will never understand but I see happening. I don't pretend to be a scientist. But I see what I'm doing is working. I've always
"Those problems will go away if we manage what's right here. And we don't have to spend lots and lots and lots of money to do all that-we just need to do it individually."

Frank Bender

been focused on getting the crop emerged, getting it leafed out to get the ground covered-and that's a natural herbicide, the shade. It keeps weeds from germinating. I was always focusing on that plant. But now it's kind of evolved, where I'm more interested in what's happening underground. They claim more than half the plant is under the ground in the root mass. So how can we affect that? These microbes, hopefully, will be something that in time we'll understand more. I think that if these soils get in better balance, and...the biological things working in the soil, I think that we possibly may see less weed pressure because the cover crops and the cash crops will dominate the field and there will be less weed germination. We have a tremendous weed bank, but if we don't have as many of them sprouting and going to seed, then eventually maybe we can reduce herbicide use," said Bender.

"I know I need to look beyond my little farm and be concerned about, you know, the hypoxia in the Gulf of Mexico and all the pollutants that are going into Lake Erie. That is true, but I just want to do it right, here. Those problems will go away if we manage what's right here. And we don't have to spend lots and lots and lots of money to do all that — we just need to do it individually."

\section{ACKNOWLEDGEMENT}

This work was part of a regional collaborative project supported by the USDA-National Institute of Food and Agriculture (NIFA), Award No. 2011-6800230190, Cropping Systems Coordinated Agricultural Project: Climate Change, Mitigation, and Adaptation in Corn-based Cropping Systems.

\section{REFERENCE}

Michigan Department of Agriculture and Rural Development. 2016. Report: Generally Accepted Agricultural and Management Practices for Nutrient Utilization. Lansing, MI: Michigan Department of Agriculture and Rural Development. https://www.michigan. gov/documents/mdard/2016_NUTRIENT_ UTILIZATION_GAAMPs_516133_7.pdf. 